\title{
Effect of propionic and potassium sorbate supplementation on quality and performance of sugarcane tops silage
}

\author{
Digvijay Singh, Ramdev Yadav and Nitin Tyagi
}

Received: 11 September $2021 /$ Accepted: 19 September $2021 /$ Published online: 31 October 2021

(C) Indian Dairy Association (India) 2021

\begin{abstract}
The objective of present study was to evaluate the effects of chemical additives on the quality parameters and nutritive value of sugarcane tops (SCT) silages. The trial was carried out in a completely randomized experimental design with total twelve treatments including two controls, C1 (without additive) and $\mathrm{C} 2$ (with common additives viz., $0.5 \%$ Urea, $0.5 \%$ $\mathrm{NaCl}$ and $2 \%$ molasses on wet basis). However, ten treatments (C2+ other chemical additives viz., SB; Soidum benzoate, PS; Potassium sorbate, PA; propionic acid and their combinations) were applied@0.1\% (wet basis) onto the fresh SCT and ensiled for 30 days in $3.5 \mathrm{~L}$ vacuum sealed plastic jars in two replicates of each treatment. The analyzed variables were: chemical composition, quality parameters and nutritive values. Selection of most promising additive/combination was done with Flieg point and fitness values. The addition of chemical additive before ensiling produced silages with better quality indices $(\mathrm{pH}$, lactic acid, Flieg point and fitness values), higher nutritive value (crude protein and $\mathrm{ME}$ ) and low NDF as compared to control with additive (C2). Ammonia Nitrogen $\left(\mathrm{NH}_{3} \mathrm{~N} \% \mathrm{TN}\right)$ and protein fractionation (NDICP and ADICP) were also considered for the identification of best SCT top silage and chemical additive effect. The results
\end{abstract}

Animal Nutrition Division, ICAR-National Dairy Research Institute, Karnal-132001, Haryana, India.

Nitin Tyagi $(\bowtie)$

Animal Nutrition Division, ICAR-National Dairy Research Institute, Karnal-132001, Haryana, India.

E-mail:drnitinvet@gmail.com; Phone: +918307164284 of present study indicate that PA and PS $+\mathrm{PA}$ were the most promising additive treatments for the improving the SCT silage quality and nutritive value. Furthermore, information extended from the present study is giving future direction towards animal feeding trials with SCT silage with chemical additive.

Keywords: Propionic acid, Quality, Sodium sorbate Nutritive values, Sugarcane tops Silage

\section{Abbreviation}

ADF, acid detergent fiber; ADICP, acid detergent fiber insoluble protein; CP, crude protein; DM, dry matter; EE, ether extract; FM, fresh matter; LA, lactic acid; ND, no detected; NDF, neutral detergent fibre assayed with a heat stable amylase and expressed inclusive of residual ash; NDICP, neutral detergent fibre insoluble protein, SCT, sugarcane tops SB, Soidum benzoate; PS, Potassium sorbate; PA, propionic acid

\section{Introduction}

Fodder management plays a pivot role in successful dairy farming and the utilisation of alternate fodder resources or crops reduces the stress on existing conventional feed resources. The sugarcane (Saccahrum officinarum) is among the largest commercial crop of India, over 282 lakh tons of sugarcane and 34.6 MMT sugarcane tops (SCT) are produced annually (ISMA, 2019). However, a large portion of this remained left as such on field or burnt in the field (Pandey et al. 2009). Ensiling is post-harvesting management and find most effective on improving digestible energy content of poor quality fodder by solubilising the fibrous (NDF and ADF) structure. Although, uncontrolled yeast and mold risk and clostridia growth, poor aerobics stability, high $\mathrm{NH}_{3} \mathrm{~N} \%$ $\mathrm{TN}$, and butyric acid concentration are common with sugarcane tops silage preparation (Khanal et al. 1995; Kebede et al. 2018). This might be a resultant of poor fermentation process, the low water soluble sugar contents and high buffering capacity, which in turn increases dry matter losses and lowers its nutritive value (Soundharrajan et al. 2021).

Sugarcane tops are poor quality lignin-rich roughages having limited cell wall degradability, low protein and energy 
content (Akinbode et al. 2017). Kebede et al. (2018) prepared SCT silage with urea $(1 \% \mathrm{FM})$ and molasses $(4 \% \mathrm{FM})$ and reported nitrogen content and nutritional value improvements. Use of additives and nutrient supplementation during ensiling can improve the silage quality parameters; secondly, ensiling would facilitate the utilisation of poor quality fodder of higher NDF and ADF in animal diet. There is a negative relation between higher NDF and ADF with fibre digestibility and dry matter intakes in animals (Mahyuddin 2008). Alli et al. (1982) reported ADF levels reduced from $43.1 \%$ to $29.9 \%$ in sugarcane tops silage prepared with additive treatment. Similarly, Pedroso et al. (2011) reported an improvement in energy content of sugarcane silage on addition of sodium benzoate $(1 \mathrm{~g} / \mathrm{kg}$ fresh matter basis) as compared to untreated silage. Data availability on improving the sugarcane tops silage quality with the use of chemical additives is still restricted and inconclusive. Therefore, present invitro study was conducted to identify the most promising chemical additives that can improve quality, fermentation characteristics and nutritive value of SCT silage and can also provide most promising chemical additives for successful crop residues ensiling.

\section{Materials and Methods}

\section{Forage harvesting for silage preparation}

The study was conducted at the National Dairy Research Institute, Karnal, Haryana, India. Sugarcane tops were procured after cutting stem during the harvesting period. Whole sugarcane tops were chaffed into $2-4 \mathrm{~cm}$ particle length using an electrical chaff cutter. At the time of ensiling DM content was the $30.0 \%$. Urea $(0.5 \%), \mathrm{NaCl}(0.5 \%)$ and molasses $(2 \%)$ were added in all treatment groups as common additive. Before this, molasses was treated with dilute sulphuric acid@2\% FM basis which hydrolyses large sucrose molecule to glucose and fructose.

\section{Schedule of ensiling experiment}

The chopped sugarcane tops were evenly mixed with chemical additives and respective chemical additive divided into two replicates and packed in plastic jar silos vacuum-sealed containers of 3.5 L capacity (CELLO, Packing Co. Ltd., India). A total of 24 jars (12 sets of SCT silage including two controls $(\mathrm{C} 1$ and $\mathrm{C} 2) \times 2$ replicates) were packed and kept in the laboratory at ambient temperature (at $21 \pm 1^{\circ} \mathrm{C}$ ), for 30 days of ensiling. The two controls were $(\mathrm{C} 1)$ without additives and (C2) added with common additives $(0.5 \% \mathrm{NaCl}, 0.5 \%$ Urea and $2 \%$ molasses $)$ treatments. Excluding the two controls $\mathrm{C} 1$ and $\mathrm{C} 2$, total 10 treatments were prepared out of which seven were mixed with common additive plus different chemical additive combinations [Sodium benzoate (SB), Potassium sorbate (PS) and Propionic acid (PA), SB+PS, $\mathrm{SB}+\mathrm{PA}, \mathrm{PS}+\mathrm{PA}$ and $\mathrm{SB}+\mathrm{PS}+\mathrm{PA}]$ added at the dose rate $0.1 \%$ as such basis. Other three treatments were prepared with $0.5 \% \mathrm{NaCl}$, $0.5 \%$ urea and $2 \%$ Molasses, respectively on as fresh basis.

\section{Proximate and cell wall constituent analysis}

DM contents were determined by oven drying at $65^{\circ} \mathrm{C}$ for $72 \mathrm{~h}$ and ground to pass a 1-mm screen. Dry matter loss was determined by ashing of fresh fodder and silage samples (Dickerson et al. 1991; Ashbell and Weinberg, 1992)

$$
\mathrm{DM} \operatorname{loss}(\%)=\left[1-\left(\operatorname{ash}_{\mathrm{fresh}} / \operatorname{ash}_{\text {silage })}\right] * 100\right.
$$

Crude protein (CP) and ether extract (EE) were analysed according to standard procedures detailed by the AOAC (2005). The neutral detergent fibre (NDF) and ADF were analysed as per Van Soest et al. (1991). Acid detergent insoluble protein (ADICP), neutral detergent insoluble protein (NDICP) was estimated as per Licitra et al. (1996). The TDN content and ME contents of silage samples were estimated as per the equations given by NRC(2001).

\section{pH, buffering capacity, flieg point and fitness value analysis}

The $\mathrm{pH}$ was measured by using a Eutech $\mathrm{pH}$ meter (Oakton Instruments, IL USA) and the buffering capacity of the sample was done as per the method of Playne and McDonald (1996). 10 $\mathrm{g}$ of fresh silage material was macerated with $250 \mathrm{ml}$ of distilled water and filtered through Whatman filter paper no.1. The $\mathrm{pH}$ of this extract was immediately measured. For buffering capacity, the macerated sample was first titrated to $\mathrm{pH} 3$ with $0.1 \mathrm{~N}$ hydrochloric acid to release bicarbonate as carbon dioxide and then titrated to $\mathrm{pH} 4$ and then to $\mathrm{pH} 6$ with $0.1 \mathrm{~N}$ sodium hydroxide. Buffering capacity was expressed as mill equivalent of alkali required to change $\mathrm{pH}$ from 4 to 6 per $100 \mathrm{~g}$ DM. To assess the quality of the silage, Flieg points from the $\mathrm{pH}$ value and $\mathrm{DM}$ of silage were measured at the end of the fermentation period with the following equation (Moselhy et al. 2015).

\section{Flieg points $=220+[(2 * D M " 15)] " 40 * \mathrm{pH}$}

The suggested score by authors were as follows, very bad for $<$ 20 , bad with a score between 21 to 40 ; to be medium with a score between 41 to 60 ; to be good (61 to 80 ) and to be very good when it had a score above 81 . The estimation of lactic acid in silage samples was done as per the method of Barker and Summerson (1941) and modified by Barnett (1951) and for $\mathrm{NH}_{3}-\mathrm{N}$ estimation, $2 \mathrm{ml}$ of water extract was taken in micro Kjeldahl apparatus and contents made alkaline with $40 \% \mathrm{NaOH}$ solution. Steam distillation was done using KEL PLUS - $\mathrm{N}$ analyzer (Pelican, India) and the $\mathrm{NH}_{3}$ evolved was collected in a boric acid solution having a mixed indicator and titrated against $\mathrm{N} / 100 \mathrm{H}_{2} \mathrm{SO}_{4}$.

\section{Experimental design and statistical analysis}

The data was subjected to one -way analysis of variance (ANOVA) with the fixed effects of additives and ensiling period using the general linear model procedure of SPSS (20.0). Pairwise comparisons of the mean values were tested by Duncan multiple 
range test (Duncan 1955) and the Hypothesis testing was done at a $5 \%$ signiûcance level.

\section{Results and Discussion}

\section{Chemical composition}

The dry matter, NDF and ADF contents (Table 1) of fresh sugarcane tops are in agreement with the values reported in literature. Chemical composition of fresh sugarcane tops reported in several studies varies with working cultivars of sugarcane (Andrade et al. 2002; Santos et al. 2009). Dry matter content ranged between 24 and $37 \%$, NDF between 36 and $56 \%$ and ADF between 21 and $36 \%$, although, the crude protein content is within the range of 3.80 to $6.70 \%$ of the dry matter (Kebede et al. 2018).

After 30 days of ensiling, chemical composition (DM, CP, EE, $\mathrm{OM}$ and NDF) of sugarcane tops silages prepared with different chemical additive are presented (Table 2). Results suggested that DM content increased in control C2 (with common additive) and all treatments with chemical additives combination, highest in SB+PA, PS+PA, SB+PS, SB+PS+PA followed by PS, SB and PA. This might be due to added mass of different salts. Present study has shown that the total ash $(\% \mathrm{DM})$ content was higher $(\mathrm{P}<$ 0.05 ) in treatment groups $\mathrm{SB}+\mathrm{PS}+\mathrm{PA}, \mathrm{SB}+\mathrm{PS}$. Other studies have also reported that the ash content was increased on addition of chemical additive (Santos et al. 2009). In relation to control C1 (without additives) SCT silage, the CP content was $(\mathrm{P}<0.05)$ found higher in all additive treatments and control $\mathrm{C} 2$. The $\mathrm{CP}$ content was increased $(\mathrm{P}<0.05)$ by $62.80,54.84,38.91 \%$ in $\mathrm{SB}+\mathrm{PS}$, $\mathrm{PS}, \mathrm{SB}+\mathrm{PS}+\mathrm{PA}$ treatments with respect to the control C1 (without additive). Increase in silage nitrogen content might be due to urea addition; Schmidt et al. (2007) have reported at $0.5 \% \mathrm{FM}$ urea addition, nitrogen recovery was 75 percent. EE content ranged from 1.88 to $3.22(\% \mathrm{DM})$ among all the treatments. Buffering capacity in all additive treatment groups remained similar to the control ( $\mathrm{C} 1$ and $\mathrm{C} 2$ ), it ranged from 97.33 to 52.69 (meqNaOH/100g DM), however, it significantly $(\mathrm{P}<0.05)$ increased in urea treated SCT silage. SCT silage prepared with

Table 1 Chemical composition (g/100g DM), pH, buffering capacity of fresh sugarcane tops

\begin{tabular}{|c|c|}
\hline Parameter & Mean ( \pm standard deviation) \\
\hline$\overline{\mathrm{DM}(\% \mathrm{FM})}$ & $30.00 \pm 0.58$ \\
\hline Crude protein $(\% \mathrm{DM})$ & $6.61 \pm 0.09$ \\
\hline Ether extract (\% DM) & $2.66 \pm 0.08$ \\
\hline Organic matter (\% DM) & $92.54 \pm 0.01$ \\
\hline Total ash (\% DM) & $7.46 \pm 0.01$ \\
\hline NDF $(\% \mathrm{DM})$ & $77.37 \pm 0.19$ \\
\hline $\mathrm{ADF}(\% \mathrm{DM})$ & $44.40 \pm 0.07$ \\
\hline Hemicellulose (\% DM) & $32.97 \pm 0.16$ \\
\hline NDICP (\% DM) & $1.9 \pm 0.49$ \\
\hline ADICP (\% DM) & $0.93 \pm 0.01$ \\
\hline $\operatorname{ADL}(\% \mathrm{DM})$ & $6.16 \pm 0.42$ \\
\hline TDN $(\% \mathrm{DM})^{\mathrm{a}}$ & $58.01 \pm 1.02$ \\
\hline $\mathrm{ME}(\mathrm{MJ} / \mathrm{kg} \mathrm{DM})^{\mathrm{a}}$ & $8.48 \pm 0.84$ \\
\hline $\mathrm{pH}$ & $6.82 \pm 0.04$ \\
\hline Buffering capacity (Meq \% DM) & $36.16 \pm 2.33$ \\
\hline
\end{tabular}

DM, dry matter; FM, fresh matter; NDF, neutral detergent fiber; ADF, Acid detergent fibre, NDICP, neutral detergent fiber insoluble protein; ADICP, Acid detergent insoluble protein, $\mathrm{ME}$, metabolisable energy, TDN, total digestible nutrient estimated by NRC, 2001,

Table 2 Chemical composition and nutritive value of sugar cane treated with additives at the time of ensiling

\begin{tabular}{|c|c|c|c|c|c|c|c|}
\hline Treatment & $\begin{array}{l}\text { DM(Freeze } \\
\text { dried) }\end{array}$ & $\begin{array}{l}\mathrm{CP}(\% \\
\mathrm{DM})\end{array}$ & $\begin{array}{l}\mathrm{EE}(\% \\
\mathrm{DM})\end{array}$ & $\begin{array}{l}\text { Buffering } \\
\text { capacity } \\
\text { (meqNaOH \% DM) }\end{array}$ & $\begin{array}{l}\text { ASH } \\
(\% \mathrm{DM})\end{array}$ & NDF (\% DM) & $\mathrm{ADF}(\% \mathrm{DM})$ \\
\hline$\overline{\mathrm{SB}}$ & $34.27^{\mathrm{c}}$ & $8.41^{\mathrm{abc}}$ & $2.90^{\mathrm{ab}}$ & $84.92^{\mathrm{ab}}$ & $10.36^{\mathrm{ab}}$ & $67.20^{\mathrm{fj}}$ & $40.29^{f}$ \\
\hline $\mathrm{SB}+\mathrm{PS}$ & $34.39^{c}$ & $9.41^{\mathrm{a}}$ & $2.47^{\mathrm{abc}}$ & $75.96^{b}$ & $14.52^{\mathrm{c}}$ & $67.83^{\mathrm{ef}}$ & $40.23^{\mathrm{f}}$ \\
\hline $\mathrm{SB}+\mathrm{PA}$ & $36.38^{\mathrm{a}}$ & $8.37^{\mathrm{abc}}$ & $2.49^{\mathrm{abc}}$ & $68.66^{\mathrm{bc}}$ & $11.96^{\mathrm{b}}$ & $65.79^{k}$ & $38.29^{\mathrm{j}}$ \\
\hline PS & $33.47^{\mathrm{cd}}$ & $8.95^{\mathrm{ab}}$ & $3.22^{\mathrm{a}}$ & $72.00^{\mathrm{bc}}$ & $9.72^{\mathrm{a}}$ & $66.53^{\mathrm{jk}}$ & $41.45^{\mathrm{d}}$ \\
\hline $\mathrm{SB}+\mathrm{PS}+\mathrm{PA}$ & $34.27^{c}$ & $8.73^{\mathrm{ab}}$ & $2.64^{\mathrm{abc}}$ & $67.17^{\mathrm{bc}}$ & $14.03^{\mathrm{c}}$ & $68.54^{\mathrm{de}}$ & $40.82^{\mathrm{e}}$ \\
\hline Urea & $28.14^{\mathrm{f}}$ & $8.04^{\mathrm{abc}}$ & $3.37^{\mathrm{a}}$ & $97.33^{\mathrm{a}}$ & $10.79^{\mathrm{ab}}$ & $73.83^{\mathrm{a}}$ & $43.50^{\mathrm{a}}$ \\
\hline Molases & $32.48^{\mathrm{e}}$ & $7.01^{\mathrm{cd}}$ & $2.60^{\mathrm{abc}}$ & $68.15^{\mathrm{bc}}$ & $8.92^{\mathrm{a}}$ & $71.68^{\mathrm{a}}$ & $42.16^{\mathrm{bc}}$ \\
\hline $\mathrm{NaCl}$ & $28.12^{\mathrm{f}}$ & $9.16^{\mathrm{ab}}$ & $2.40^{\mathrm{abc}}$ & $69.28^{\mathrm{bc}}$ & $9.32^{\mathrm{a}}$ & $71.90^{\mathrm{b}}$ & $41.74^{\mathrm{cd}}$ \\
\hline $\mathrm{Cl}$ & $28.30^{\mathrm{f}}$ & $5.78^{d}$ & $2.01^{\mathrm{bc}}$ & $52.69^{\mathrm{bc}}$ & $8.53^{\mathrm{a}}$ & $70.41^{\mathrm{c}}$ & $42.35^{\mathrm{b}}$ \\
\hline
\end{tabular}

Means within a column which are not followed by a common superscript letter are significantly different $(\mathrm{P}<0.05)$ $\mathrm{SEM}=$ Standard error of mean MSS; $\mathrm{C} 1$, without additive, $\mathrm{C} 20.5 \% \mathrm{NaCl}, 0.5 \%$ Urea and $2 \%$ molasses on $\mathrm{FM}$ basis SB, Sodium benzoate; PS, Potassium sorbate; PA, Propionic acid added @ 0.1\% on FM basis 
Table 3 Quality parameters of sugarcane tops silage after 30 day of ensiling with deferent chemical additive treatments

\begin{tabular}{|c|c|c|c|c|c|c|}
\hline Treatment & $\mathrm{pH}(30 \mathrm{~d})$ & $\begin{array}{l}\text { Lactic } \\
\operatorname{acid}(\mathrm{g} /\end{array}$ & $\begin{array}{l}\text { DM loss (\%) } \\
\text { 1) }\end{array}$ & $\begin{array}{l}\text { NH -N } \\
\text { (\% o of total-N) }\end{array}$ & $\begin{array}{l}\text { NDICP } \\
(\% \mathrm{CP}) \\
\end{array}$ & $\begin{array}{l}\mathrm{ADICP} \\
(\% \mathrm{CP})\end{array}$ \\
\hline$\overline{\mathrm{SB}}$ & $5.09^{\mathrm{d}}$ & $5.69^{\mathrm{bcd}}$ & $4.35^{\text {cde }}$ & $19.29^{\circ}$ & $27.83^{\alpha}$ & $15.41^{\text {at }}$ \\
\hline $\mathrm{SB}+\mathrm{PS}$ & $4.92^{\mathrm{e}}$ & $4.98^{\mathrm{cd}}$ & $3.70^{\mathrm{e}}$ & $26.36^{b}$ & 18.81 & $9.94^{\mathrm{c}}$ \\
\hline $\mathrm{SB}+\mathrm{PA}$ & $4.82^{\mathrm{e}}$ & $5.23^{\text {bcd }}$ & $5.46^{\text {abcd }}$ & $39.58^{\mathrm{a}}$ & 17.64 & $10.45^{\mathrm{c}}$ \\
\hline PS & $4.57^{\mathrm{f}}$ & $6.00^{\mathrm{bc}}$ & $3.88^{\mathrm{de}}$ & $36.33^{\mathrm{a}}$ & 15.88 & $8.68^{\mathrm{c}}$ \\
\hline $\mathrm{PS}+\mathrm{PA}$ & $4.45^{\mathrm{f}}$ & $6.58^{\mathrm{b}}$ & $5.08^{\text {abcde }}$ & $38.72^{\mathrm{a}}$ & 19.03 & $10.56^{\mathrm{c}}$ \\
\hline PA & $4.22^{\mathrm{j}}$ & $8.57^{\mathrm{a}}$ & $4.75^{\text {abcde }}$ & $29.97^{\mathrm{b}}$ & 17.83 & $9.71^{\mathrm{c}}$ \\
\hline $\mathrm{SB}+\mathrm{PS}+\mathrm{PA}$ & $4.47^{\mathrm{f}}$ & $6.16^{\mathrm{bc}}$ & $4.30^{\text {cde }}$ & $26.09^{\mathrm{b}}$ & 18.04 & $11.84^{\mathrm{bc}}$ \\
\hline Urea & $5.94^{\mathrm{b}}$ & $5.45^{\text {bcd }}$ & $6.24^{\mathrm{ab}}$ & $16.37^{c}$ & 18.05 & $12.08^{b}$ \\
\hline Molasses & $5.75^{\mathrm{c}}$ & $5.34^{\text {bcd }}$ & $4.84^{\text {abcde }}$ & $19.58^{\mathrm{c}}$ & 18.29 & $8.67^{c}$ \\
\hline $\mathrm{NaCl}$ & $4.51^{\mathrm{f}}$ & $6.61^{\mathrm{b}}$ & $6.90^{\mathrm{a}}$ & $42.59^{\mathrm{a}}$ & 19.93 & $17.11^{\mathrm{a}}$ \\
\hline $\mathrm{Cl}$ & $5.94^{\mathrm{b}}$ & $4.53^{\mathrm{d}}$ & $5.62^{\mathrm{abc}}$ & $39.02^{\mathrm{a}}$ & 24.00 & $10.43^{c}$ \\
\hline $\mathrm{C} 2$ & $6.14^{\mathrm{a}}$ & $4.33^{\mathrm{d}}$ & $4.92^{\mathrm{abcde}}$ & $37.09^{\mathrm{a}}$ & 18.67 & $10.01^{\mathrm{c}}$ \\
\hline SEM & 0.11 & 0.19 & 0.17 & 1.56 & 0.82 & 0.50 \\
\hline
\end{tabular}

Means within a column which are not followed by a common superscript letter are significantly different $(\mathrm{P}<0.05)$

ADICP, acid detergent fiber insoluble protein; NDICP, neutral detergent fiber insoluble protein; NH3-N, ammonia nitrogen \% total nitrogen

Table 4 Nutritive values and Flieg point values of sugarcane tops silage under deferent additive treatments

\begin{tabular}{lllll}
\hline Treatment & TDN $(\%$ DM $)$ & ME $(\mathrm{MJ} / \mathrm{kg} \mathrm{DM})$ & Flieg point & Fitness value \\
\hline SB & $58.15^{\mathrm{ab}}$ & $9.06^{\mathrm{a}}$ & $69.95^{\mathrm{f}}$ & $0.49^{\text {cd }}$ \\
SB+PS & $58.63^{\mathrm{ab}}$ & $8.97^{\mathrm{a}}$ & $76.97^{\mathrm{e}}$ & $0.51^{\mathrm{c}}$ \\
SB+PA & $59.21^{\mathrm{a}}$ & $9.02^{\mathrm{a}}$ & $85.17^{\mathrm{cd}}$ & $0.48^{\mathrm{de}}$ \\
PS & $59.94^{\mathrm{a}}$ & $9.19^{\mathrm{a}}$ & $89.34^{\mathrm{c}}$ & $0.53^{\mathrm{b}}$ \\
PS+PA & $59.43^{\mathrm{a}}$ & $9.02^{\mathrm{a}}$ & $97.65^{\mathrm{ab}}$ & $0.53^{\mathrm{b}}$ \\
PA & $58.76^{\mathrm{ab}}$ & $9.00^{\mathrm{a}}$ & $100.79^{\mathrm{a}}$ & $0.56^{\mathrm{a}}$ \\
SB+PS+PA & $59.38^{\mathrm{a}}$ & $8.82^{\mathrm{ab}}$ & $94.73^{\mathrm{b}}$ & $0.56^{\mathrm{a}}$ \\
Urea & $52.04^{\mathrm{e}}$ & $7.75^{\mathrm{c}}$ & $23.87^{\mathrm{k}}$ & $0.46^{\mathrm{ef}}$ \\
Molasses & $56.82^{\mathrm{bc}}$ & $8.51^{\mathrm{b}}$ & $39.96^{\mathrm{j}}$ & $0.50^{\text {cd }}$ \\
NaCl & $51.60^{\mathrm{e}}$ & $7.71^{\mathrm{c}}$ & $80.84^{\mathrm{de}}$ & $0.44^{\mathrm{f}}$ \\
C1 & $54.99^{\mathrm{cd}}$ & $8.11^{\mathrm{c}}$ & $24.20^{\mathrm{k}}$ & $0.53^{\mathrm{b}}$ \\
C2 & $53.34^{\mathrm{de}}$ & $8.04^{\mathrm{c}}$ & $25.44^{\mathrm{k}}$ & $0.50^{\mathrm{cd}}$ \\
SEM & 0.50 & 0.09 & 4.93 & 0.01 \\
\hline
\end{tabular}

Means within a column which are not followed by a common superscript letter are significantly different $(\mathrm{P}<0.05)$

Means within columns with different superscripts differ $(\mathrm{P}<0.05)$

ME, Metabolisable energy; TDN, total digestible nutrient estimated by NRC, 2001.

different treatment had $(\mathrm{P}<0.05)$ variations in cell wall components (NDF, ADF), which has been depicted in the Table 2. Cell wall component (NDF, ADF) in all additive treated SCT silage was found lower $(\mathrm{P}<0.05)$ than control $(\mathrm{C} 1$ and $\mathrm{C} 2)$. The reduction in NDF, $\mathrm{ADF}$ was higher in chemical additives $\mathrm{SB}+\mathrm{PA}$, $\mathrm{PS}, \mathrm{PS}+\mathrm{PA}, \mathrm{SB}+\mathrm{PS}$ treated sugarcane tops silages, which is an indicative effect of chemical additives can degrade structural carbohydrates to water soluble carbohydrate and improve silage quality and fibre digestibility. Similar to our findings Siqueira et al. (2007) has observed higher hemicellulose solubilisation and degradation in sugarcane silage on sodium benzoate $(0.1 \mathrm{FM})$ treatment and resulting in increased $(\mathrm{P}<0.05)$ IVDMD in treatment groups i.e. 61.1 against $39.4 \%$ to the control.

\section{Quality parameters}

Silage samples were analysed on $30^{\text {th }}$ day of ensiling for $\mathrm{pH}$ and lactic acid content, the values are presented in Table 3 . The $\mathrm{pH}$ content of ensiled SCT silage ranged from 4.45 to 6.14 respectively. In relation to control $(\mathrm{C} 1$ and $\mathrm{C} 2)$ all the additive treatment group has low $(\mathrm{P}<0.05) \mathrm{pH}$ values and were minimum in treatments $\mathrm{PA}, \mathrm{PS}+\mathrm{PA}, \mathrm{SB}+\mathrm{PS}+\mathrm{PA}$ and $\mathrm{PS}$ sugarcane tops silages. The $\mathrm{pH}$ value of additive treated SCT silage was within the ideal range, indicating a good fermentation characteristic (McDonald et al. 1995, Kebede et al. 2018). Buffering effect of urea attributes the slower decline in $\mathrm{pH}$ (Kebede et al. 2018). Results from present study suggested clear relationship between 
decline in $\mathrm{pH}$ and increase $(\mathrm{P}<0.05)$ in Lactic Acid content (g/ $100 \mathrm{~g} \mathrm{DM}$ ) in all additive treated SCT silages as compared to control $\mathrm{C} 1$ and $\mathrm{C} 2$. A similar result of lower $\mathrm{pH}$ values was reported by Siqueira et al. (2007), their study in which sodium benzoate was added at 0.1 percent FM in sugarcane tops silage. In the present study, mean Dry matter loss (DML \% DM) of control SCT silage was approximately similar to the other studies by Pedroso et al. (2007) and Kebede et al. (2018). However, the dry matter loss on chemical additive treatment was higher and the values ranged from 31.12 to 12.85 (\% DM). This might be a cumulative loss of dry matter occurred during fermentation, or due to urea treatment. Additionally, Kung and Shaver (2001); Kebede et al. (2018) has reported urea treatment of SCT at $0.5 \%$ FM accomplished a significant higher DM loss than control silage, while adding molasses with urea can counteract the DML by urea. In contrary to this, Pedroso et al. (2011) in their study also reported DML in sugarcane silage reduced by $31 \%$ when added with $0.5 \%$ urea FM.

In present study, NH3-N (\% TN) increased $(\mathrm{P}<0.05)$ in $\mathrm{C} 2$ (with common additive) and chemical additive treatment as compared to the control C1 (additive free) SCT silage. Obtained results indicate that ammonia nitrogen increased by addition of urea in all groups. However, SCT silage treated with propionic acid had the lowest $\mathrm{NH}_{3} \mathrm{~N}(\% \mathrm{TN})$ as similar to control without additive treatment $(\mathrm{C} 1)$. These finding on propionic acid addition from present study agreed with previous report (Winters et al. 2001) and the explanation that the addition of propionic acid during ensiling suppresses the proteolysis and plant enzyme activity which simultaneously improved amino acid balance and reduces the $\mathrm{NH}_{3}-\mathrm{N}$ concentrations. ADICP is one of the important parameters of silage quality and was used to assess the successful ensiling technique. The ADICP of the silage was expressed in terms of ADICP $(\% \mathrm{CP})$ of SCT silage is presented in Table 3 . The results indicated that ADICP (\% CP) obtained for SCT silage sample was significantly higher in urea $(0.5 \% \mathrm{FM})$ and other chemical additive added SCT silage, while other treatments were similar to the control $\mathrm{C} 1$ and $\mathrm{C} 2$. ADICP content is defined as the fraction of crude protein which remained unavailable to the animals, ADICP content $>12 \% \mathrm{CP}$ suggests excess heat damaged protein produced or Maillard reaction occurred between carbohydrate and ammonia due poor ensiling (Yu and Thomas, 1976).

\section{Nutritive values and Flieg point}

Nutritive value especially energy content, TDN (\%DM) and ME $(\mathrm{MJ} / \mathrm{kg} \mathrm{DM})$ of sugarcane tops silage ranged from 51.60 to 59.94 and 7.71 to 9.19 respectively (Table 4 ). Results from the study depicts that the TDN and ME content $(\mathrm{P}<0.05)$ increased in all chemical additive treated SCT silage as compared to the control $\mathrm{SCT}$ silage $\mathrm{C} 1$ and $\mathrm{C} 2$. The values were highest for treatment $\mathrm{PS}$ followed by PS+PA, and PA and lowest in $\mathrm{NaCl}$ and $\mathrm{C} 1$ treatment SCT silage. The ME value of intact SCT was reported to be 7.0
$\mathrm{MJ} / \mathrm{kg}$ DM (McKenzie and Griffiths, 2007). Akinbode et al. (2017) have reported ME of SCT silage was increased on ensiling as attributed to the increased NFC content compared to fresh sugarcane tops. Pedroso et al. (2011) assessed the effect of various chemical and biological additives for quality sugarcane silage and reported that silage treated with sodium benzoate $(1 \mathrm{~g} / \mathrm{kg}$ fresh matter basis) had a higher TDN content compared to untreated silage, which indicates that sodium benzoate treatment improved the nutritional value of sugarcane silage. Flieg point values of $\mathrm{C} 1$ and $\mathrm{C} 2 \mathrm{SCT}$ silage was 24.20 and 25.44 , respectively, all additive treatments were higher $(\mathrm{P}<0.05)$ in Flieg point than control C1 and C2 SCT silage. According to Flieg point score (Moselhy et al. 2015) all the additive treated SCT silage was of very good quality. Flieg point and fitness value were highest in treatment PA followed by PS+PA. The Fitness value was also higher $(\mathrm{P}<0.05)$ in all additive treated SCT silage, which suggested for PA and PS+PA additives were the most promising additive for the improving the silage quality and nutritive value. Results from the study can provide important information on selection of best chemical additive and considering for feeding trail in dairy animals.

\section{Conclusion}

Chemical additive supplementation before ensiling can improve sugarcane tops silage quality parameters and nutritive values. Addition of chemical additive improved protein and energy content by fibrous solubilisation by chemical additive treatment. The values of ammonia nitrogen $\left(\mathrm{NH}_{3} \mathrm{~N} \% \mathrm{TN}\right)$, ADICP, flieg point and fitness value are considered tool for the selection most promising chemical additives. The potassium sorbate and propionic acid and their combination were found most promising chemical additive in the study, added at the dose rate $1 \mathrm{~g} \mathrm{per} \mathrm{kg}$ sugarcane tops on wet basis. Furthermore, feeding trail recommended for assessing effect of these chemical additives on feed intake and nutrient utilisation in animals.

\section{Acknowledgments}

The authors acknowledge fellowship and infrastructure received from ICAR-NDRI (Karnal) to carry out the research work

\section{Reference}

Akinbode R M, Isah O A, Oni AO, Arigbede OM, Ojo VOA(2017) Nutritional evaluation of sugarcane top ensiled with varying proportion of broiler litter. Livest Res Rural Dev 29.

Alli I, Baker BE, Garcia G (1982) Studies on the fermentation of chopped sugarcane. Anim Feed Sci and Technol 7: 411-417.

Andrade JB, Ferrari Júnior E, Possenti RA, Otsuk IP, Zimback L, Landell MGA (2002) Produção E Composição De Cultivares De Cana-DeAçúcar. Anais. Recife: Sbz, Cd-Rom. ReuniãoRanual Da Sociedade Brasileira De Zootecnia. 39:1.

AOAC. (2005). Official methods of analysis (17th Ed.). Association of Official Analytical Chemists, Arlington, Virginia, USA.

Ashbell G, Weinberg ZG (1992) Top silage losses in horizontal silos. Can Agric Eng 34: 171-5. 
Barker SB, Summerson WH (1941) The colorimetric determination of lactic acid in biological material. J Bio Chem 138: 535-54.

Barnett AJ (1951) The colorimetric determination of lactic acid in silage. Biochem J 49(4):527-529.

Dickerson JT, Ashbell G, Pfaff L, Bolsen KK, Brent BE, Bradford JE, Smith RL (1991) Top spoilage losses in horizontal silos in western Kansas :71-74

Duncan DB (1955) Multiple range and multiple F tests. Biometrics.11:142

ISMA (2019) Indian sugar mills association report. The economic times report. https://www.indiansugar.com/ContactUS.aspx

Kebede G, Mengistu A, Assefa G, Animut G (2018) Nutritional and fermentative quality of sugarcane (Saccharum officinarum) top ensiled with or without urea and molasses. African J Agri Res 13(20): 1010-1017.

Khanal RC, Perera ANF, Perera ERK (1995) Ensiling characteristics and nutritive value of sugarcane tops.

Kung JrL, Sheperd AC, Smagala AM, Endres KM, Bessett CA, Ranjit NK, Glancey JL (2001) The effect of preservatives based on propionic acid on the fermentation and aerobic stability of corn silage and a total mixed ration. Dairy Sci 81:1322-1330.

Licitra G, Hernandez TM, Van Soest PJ (1996) Standardizations of procedures for nitrogen fractionation of ruminant feeds. Anim feed Sci Technol 57: $347-358$

Mahyuddin P (2008) Relationship between chemical component and in vitro digestibility of tropical grasses. HAYATI J Biosci 15: 85-89.

McDonald P, Henderson AR, Heron SJE (1991) The Biochemistry of Silage, second ed. Chalcombe Publications, Marlow, England.pp. 341.

McKenzie J, Griffiths C (2007) Cane tops as cattle fodder. New South Wales Department of Primary Industries, Primefacts, $N^{\circ} 314$.

Moselhy MA, Borba JP, Borba AE (2015) Improving the nutritive value, in vitro digestibility and aerobic stability of Hedychium gardnerianum silage through application of additives at ensiling time. Anim Feed Sci Technol 206: 8-18
National Research Council (2001) Nutrient requirements of dairy cattle: Seventh Revised Edition. National Academies Press

Pandey A, Biswas S, Sukumaran RK, Kaushik N (2001) Study on availability of Indian biomass resources for exploitation: a report based on a nation-wise survey. TIFAC, New Delhi. 105.

Pedroso A F, Nussio L, Lourdes D R (2007) Effect of treatment with chemical additives and bacterial losses and quality of silage from sugar cane. Rev Bras de Zootec J Ani Scie 36: 558-564

Pedroso ADF, Rodrigues ADA, Barioni Júnior W, Souza GBD (2011) Fermentation parameters, quality and losses in sugarcane silages treated with chemical additives and a bacterial inoculant. Rev Bras de Zootec 40: 2318-2322

Playne, M. J. and McDonald, P. (1966) The buffering constituents of herbage and of silage. J Sci Food Agric 17: 264-268

Santos MC, Nussio LG, Mourão GB, Schmidt P, Mari LJ, Ribeiro JL, Toledo Filho SGD (2009) Nutritive value of sugarcane silage treated with chemical additives. Scientia Agricola 66: 159-163

Soundharrajan I, Park HS, Rengasamy S, Sivanesan R, Choi KC (2021) Application and Future Prospective of Lactic Acid Bacteria as Natural Additives for Silage Production-A Review. Appl Sci 11:8127

Schmidt P, Mari LJ, Nussio LG, Pedroso AF, Paziani SF, Wechsler FS (2007) Aditivos químicos e biológicos na ensilagem de cana-deaçúcar. 1. Composição química das silagens, ingestão, digestibilidade e comportamento ingestivo. Rev Bras de Zootec 36:1676-1684

Siqueira GR, Reis RA, Schocken-iturrino RP, Pires AJV, Bernards TF, Amaral RC (2007) Perdas de silagens de cana-de-açúcar tratadas com aditivos químicos e bacterianos. Rev Bras de Zootec 36 (6):2000-2009.

Van Soest PV, Robertson JB, Lewis BA (1991) Methods for dietary fiber, neutral detergent fiber, and nonstarch polysaccharides in relation to animal nutrition. J Dairy Sci 74: 3583-3597

Winters AL, Fychan R, Jones R (2001) Effect of formic acid and a bacterial inoculant on the amino acid composition of grass silage and on animal performance. Grass and Forage Science, 56: 181-192

Yu Y (1976) Relationship between measurements of heating and aciddetergent insoluble nitrogen in heat damaged fresh alfalfa, haylage, and hay. J Dairy Sci 59: 1845-1849 